Scientific paper

\title{
Theoretical and Experimental Study of Organic Nano-material for Acetate Anion Based on 1, 10-phenanthroline
}

\author{
Xuefang Shang, ${ }^{1, *}$ Yuan Zhao, ${ }^{2}$ Xiaofang Wei, ${ }^{3}$ Yaqian Feng, ${ }^{3}$ \\ Xin Li, ${ }^{3}$ Shuyan $\mathrm{Gao}^{4}$ and Xiufang $\mathrm{Xu}^{5}$ \\ ${ }^{1}$ Department of Chemistry, Xinxiang Medical University, Xinxiang, Henan 453003, China \\ ${ }^{2}$ College of Foreign Languages, Henan Institute of Science and Technology, Eastern Hualan Avenue, \\ Xinxiang, Henan 453003 China \\ ${ }^{3}$ School of Pharmacy, Xinxiang Medical University, Xinxiang, Henan 453003 China \\ ${ }^{4}$ Henan Normal University, Xinxiang, Henan 453000 China \\ ${ }^{5}$ Department of Chemistry, Nankai University, Tianjin 300071, China \\ * Corresponding author: E-mail: xuefangshang@126.com \\ $\mathrm{Tel}+86-373-3029128$, Fax $+86-373-3029959$
}

Received: 29-05-2014

\begin{abstract}
New phenanthroline derivatives containing phenol groups have been synthesized and optimized. The nano-material involved bromine substituent was also developed which in the ortho- position of benzene ring. Their binding properties were evaluated for various biological anions $\left(\mathrm{F}^{-}, \mathrm{Cl}^{-}, \mathrm{Br}^{-}, \mathrm{I}^{-}, \mathrm{AcO}^{-}\right.$and $\left.\mathrm{H}_{2} \mathrm{PO}_{4}^{-}\right)$by theoretical investigation, $\mathrm{UV}_{-}$-vis, fluorescence, ${ }^{1} \mathrm{H}$ NMR titration experiments. These compounds all showed strong binding ability for AcO ${ }^{-}$without the interference of other anions tested. The anion binding ability could be regularized by electron push-pull properties of the ortho- or para- substituent on benzene. Theoretical investigation analysis revealed the effect of intramolecular hydrogen bond existed between $-\mathrm{OH}$ and other atoms in the structure of these compounds.
\end{abstract}

Keywords: nano-material, colorimetric recognition, theoretical investigation, fluorescence detection, UV-vis titration

\section{Introduction}

The growing attention on anion recognition has attracted more and more chemists due to important roles of anions in biological, chemical and environmental processes. ${ }^{1-10}$ The anion recognition by artificial receptors is an area of ever increasing research activity. ${ }^{11}$ Artifcial anion receptors have wide application prospects, such as synthesis of anion chemosensors, ${ }^{12,13}$ membrane transmit carriers and mimic enzyme catalysts, etc. ${ }^{14-16}$ The structural design of artificial receptor has been focused on the ability recognizing and binding anions. The binding units are often composed of amide, ${ }^{17}$ urea / thiourea and pyrrole owing to their binding ability performing as hydrogen donors. ${ }^{18-21}$ Anions are ubiquitous throughout biological systems. Some anions such as fluoride, chloride, bromide, acetate, dihyphosphate, and etc play important roles in a range of biological process and are implicated in many disease states. ${ }^{22}$ Especially, acetate anion displays crucial behavior and is also the important component of numerous metabolic processes. Therefore, it is significant for chemists to design and synthesize artificial receptors which can recognize and sense the acetate ion. Some compounds have been reported that they can bind acetate ion with high affnity and the acidity of the hydrogen-bond donor can be enhanced if the intramolecular hydrogen bonding exists in artificial receptor. ${ }^{23-25}$ Colorimetric sensing possesses huge advantages in practical applications as it can rapidly provide qualitative information about the analyte without any expensive instruments. ${ }^{26}$ The colori- 
metric sensing probe usually consists of two parts, the interacted site and colorimetric group which either are linked directly or by a flexible spacer. However, colorimetric anion chemosensors based on phenanthroline and $\mathrm{OH}$ group have seldom been reported. ${ }^{27-30}$ Recently, the reports of inorganic and ploymer nano-materials are very many. However, the research on small organic nano-material is very few and there are few reports about its application on the anion recognition. ${ }^{31,32}$

Bearing the above considerations, we intend to prepare phenanthroline nano-material and apply it to anion recognition. Research on this aspect can relate nano-material with supramolecular chemistry and promote the development of interdisciplinary. Expectably, a series of phenanthroline derivatives involving hydroxyl groups were synthesized (Scheme 1, 2,9-di((2',3'-diaza-4'-(2', hydroxylphenyl)-1',3'-butadiene)-1,10-phenanthroline 1; 2,9-di((2',3'-diaza-4' -(2''-hydroxyl-3''-bromophenyl)1',3'-butadiene)-1,10-phenanthroline 2; 2,9-di((2',3'-diaza-4'-(2"'-hydroxyl-3",5"'-dibromophenyl)-1',3'- butadiene)-1,10-phenanthroline 3; and 2,9-di((2',3'-diaza-4'(2'"-hydroxyl-3"' nitrophenyl)-1',3'-butadiene)-1,10phenanthroline 4). The nano-material of compound 2 was also developed. The binding-structure relationship can be revealed utilizing the intramolecular hydrogen bond as the anion-binding site by tuning different substituents. Results indicate that four compounds show the highest binding ability for acetate ion among anions tested. Importantly, these observations suggest that an oxy-anion bonding interlocked host binding domain, in combination with increased inter-component preorganisation, are requisite design features for a potent anion receptor.

\section{Experimental Section}

\section{1. Materials and Instrumentations}

Most of starting materials were obtained commercially and all reagents and solvents used were of analytical grade. 2,9-Dicarbaldehyde-1,10-phenanthroline and all anions, in the form of tetrabutylammonium salts (such as $\left(n-\mathrm{C}_{4} \mathrm{H}_{9}\right)_{4} \mathrm{NF},\left(n-\mathrm{C}_{4} \mathrm{H}_{9}\right)_{4} \mathrm{NCl},\left(n-\mathrm{C}_{4} \mathrm{H}_{9}\right)_{4} \mathrm{NBr},\left(n-\mathrm{C}_{4} \mathrm{H}_{9}\right)_{4} \mathrm{NI}$, $\left.\left(n-\mathrm{C}_{4} \mathrm{H}_{9}\right)_{4} \mathrm{NAcO},\left(n-\mathrm{C}_{4} \mathrm{H}_{9}\right)_{4} \mathrm{NH}_{2} \mathrm{PO}_{4}\right)$, were purchased from Sigma-Aldrich Chemical Co., stored in a desiccator under vacuum containing self-indicating silica, and used without any further purification. Tetra- $n$-butylammonium salts were dried for $24 \mathrm{~h}$ in vacuum with $\mathrm{P}_{2} \mathrm{O}_{5}$ at $333 \mathrm{~K}$ before using. Dimethyl sulfoxide (DMSO) was distilled in vacuo after dried with $\mathrm{CaH}_{2}$. Melting points (mp) were determined with a Reichert-Jung Thermo Galen Hot Stage Microscope and reported as uncorrected. C, H, N elemental analysis was made on Vanio-EL. ${ }^{1} \mathrm{H}$ NMR spectrum was recorded on an UNITY Plus-400 MHz Spectrometer. ESI-MS was performed with a MARINER apparatus. SEM image was obtained by Quanta TM450 FEI coating it with Au. UV-vis Spectroscopy titration was made on a Shimadzu UV2550 Spectrophotometer at 298 K. Fluorometric titration was performed on a Cary Eclipse Fluorescence Spectrophotometer at $298 \mathrm{~K}$. The affinity constant $\left(\mathrm{K}_{\mathrm{s}}\right)$ was obtained by non-linear least square calculation method for data fitting.

\section{2. Synthesis of Compound 1-4}

2,9-Dimethylenehydrazine-1,10-phenanthroline 1, 10Phenanthroline-2,9- dicarbaldehyde (1 mmol, $236 \mathrm{mg})$ in dry ethanol $(15 \mathrm{~mL})$ was added to the dry ethanol $(30 \mathrm{~mL})$ containing hydrazine hydrate $(80 \%, 0.5 \mathrm{~mL})$ under stirring. Then the mixture was heated under refuxing for $8 \mathrm{~h}$ and the yellow precipitate was separated by fltration. The solid was washed with diethyl ether and dried under vacuum. Yield: $81 \%$. mp: 279.0-281.0 ${ }^{\circ} \mathrm{C}$. ${ }^{1} \mathrm{H}$ NMR (400 MHz, DMSO- $\left.d_{6}, 298 \mathrm{~K}\right) \delta 9.52\left(\mathrm{~s}, 4 \mathrm{H}, \mathrm{NH}_{2}\right), 8.49(\mathrm{~d}, 2 \mathrm{H}$, phen-H), 8.02 (d, 2H, phen-H), 7.67(d, 2H, phen-H), 7.53 (s, 2H, CH). Elemental analysis: Calc. for $\mathrm{C}_{14} \mathrm{H}_{12} \mathrm{~N}_{6}: \mathrm{C}$, 63.62; H, 4.58; N, 31.80; Found: C, 63.93; H, 4.36; N, 31.57. ESI-MS $(m / z): 263.31(M-H)^{-}$.

Compound 1, 2, 3 and 4 were synthesized according to the following method. 2, 9-Dimethylenehydrazine-1, 10-phenanthroline (1 mmol, $264 \mathrm{mg}$ ) and 2-hydroxyl-3,
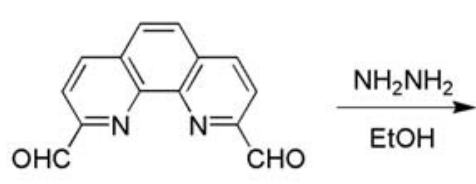

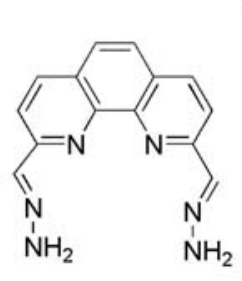

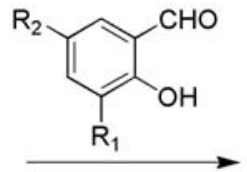

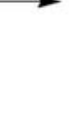

$\mathrm{R}$ 
5-disubstituents-benzaldehyde ( $1 \mathrm{mmol})$ were suspended in dry ethanol $(40 \mathrm{~mL})$. The mixture was refuxed for $12 \mathrm{~h}$ and the yellow precipitate was separated by fltration. The solid was washed with diethyl ether and dried under vacuum.

2,9-Di((2',3'-diaza-4'-(2'-hydroxylphenyl)-1',3'-butadiene)-1,10-phenanthroline (1): Yield: 79\%. mp: $>320$ ${ }^{\circ} \mathrm{C} .{ }^{1} \mathrm{H}$ NMR (400 MHz, DMSO- $\left.d_{6}, 298 \mathrm{~K}\right) \delta 11.08$ (s, 2H, OH), 8.98 (s, 4H, CH), 7.67 (dd, 4H, ph-H), 7.41-7.37 (m, 4H, ph-H), 6.98-6.94 (m, 6H, phen-H). Elemental analysis: Calc. for $\mathrm{C}_{28} \mathrm{H}_{20} \mathrm{~N}_{6} \mathrm{O}_{2}: \mathrm{C}, 71.17 ; \mathrm{H}$, 4.27; N, 17.79; Found: C, 70.89; H, 4.45; N, 17.54. ESI$\operatorname{MS}(\mathrm{m} / \mathrm{z}): 471.2(M-\mathrm{H})^{-}$.

2,9-Di((2',3'-diaza-4'-(2'-hydroxyl-3"'-bromophenyl)1',3'-butadiene)-1,10-phenanthroline (2): Yield: $88 \%$. mp: $>320{ }^{\circ} \mathrm{C} .{ }^{1} \mathrm{H}$ NMR $\left(400 \mathrm{MHz}, \mathrm{DMSO}-d_{6}, 298 \mathrm{~K}\right) \delta$ 11.21(s, $1 \mathrm{H}, \mathrm{OH}), 11.11(\mathrm{~s}, 1 \mathrm{H}, \mathrm{OH}), 8.97-8.93(\mathrm{~d}, 2 \mathrm{H}$, $\mathrm{CH}), 8.91(\mathrm{~s}, 2 \mathrm{H}, \mathrm{CH}), 8.63(\mathrm{~d}, 2 \mathrm{H}$, phen-H), $8.45(\mathrm{~d}, 2 \mathrm{H}$, phen-H) 8.12(d, 2H, phen-H), $7.95(\mathrm{~d}, 1 \mathrm{H}$, phen-H), 7.86 (d, 1H, ph-H), 7.55-7.49 (m, 2H, ph-H), 6.97-6.92 ((m, $2 \mathrm{H}$, ph-H). Elemental analysis: Calc. for $\mathrm{C}_{28} \mathrm{H}_{18} \mathrm{Br}_{2} \mathrm{~N}_{6} \mathrm{O}_{2}$ : C, 53.36; H, 2.88; N, 13.33; Found: C, 53.51; H, 2.64; N, 12.99. ESI-MS $(\mathrm{m} / \mathrm{z}): 626.8(M-\mathrm{H})^{-}$.

2,9-Di((2',3'-diaza-4'-(2"-hydroxyl-3",5"-dibromophenyl)-1',3'-butadiene)-1,10-phenanthroline (3): Yield: 82\%. mp: $>320{ }^{\circ} \mathrm{C} .{ }^{1} \mathrm{H}$ NMR (400 MHz, DMSO- $d_{6}, 298$ K) $\delta 12.26(\mathrm{~s}, 1 \mathrm{H}, \mathrm{OH}), 11.97(\mathrm{~s}, 1 \mathrm{H}, \mathrm{OH}), 9.21-9.04(\mathrm{~m}$, $6 \mathrm{H}, \mathrm{CH}$, phen- $\mathrm{H}), 8.70-8.62(\mathrm{~m}, 2 \mathrm{H}$, phen- $\mathrm{H}), 8.45(\mathrm{~d}$, $2 \mathrm{H}$, phen-H), 8.17 (d, 2H, ph-H), 7.96 (d, 2H, ph-H). Elemental analysis: Calc. for $\mathrm{C}_{28} \mathrm{H}_{16} \mathrm{Br}_{4} \mathrm{~N}_{6} \mathrm{O}_{2}: \mathrm{C}, 42.67 ; \mathrm{H}$, 2.05 ; N, 10.66; Found: C, 42.33; H, 2.45; N, 10.29. ESIMS $(\mathrm{m} / \mathrm{z}): 782.9(M-\mathrm{H})^{-}$.

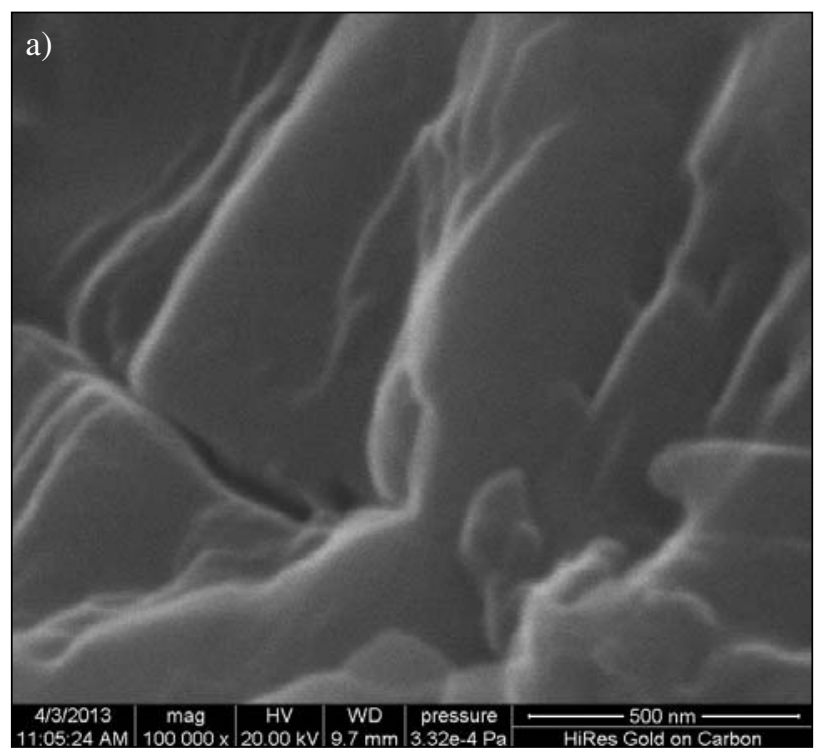

Fig. 1. SEM images of compound 2
2,9-Di((2',3'-diaza-4'-(2"'-hydroxyl-3"'-nitrophenyl)1',3'-butadiene)-1,10-phenanthroline (4): Yield: $77 \%$. mp: $>320{ }^{\circ} \mathrm{C}$. ${ }^{1} \mathrm{H}$ NMR $\left(400 \mathrm{MHz}\right.$, DMSO- $\left.d_{6}, 298 \mathrm{~K}\right) \delta$ 12.39 (s, 2H, OH), 9.18 (s, 4H, CH), 8.51-8.37 (m, 2H, phen-H), 8.20-8.03 (m, 6H, phen-H, ph-H), 7.19 (d, 4H, ph-H). Elemental analysis: Calc. for $\mathrm{C}_{28} \mathrm{H}_{18} \mathrm{~N}_{8} \mathrm{O}_{6}$ : C, 59.79; H, 3.23; N, 19.92; Found: C, 59.73; H, 3.41; N, 19.66. ESI-MS $(\mathrm{m} / \mathrm{z}): 561.2(M-\mathrm{H})^{-}$.

\section{3. Preparation of Nano-material}

The organic nano-material of compound 2 was prepared by reprecipitation method. The DMSO and the water solution of CTAB (hexadecyl trimethyl ammonium bromide) were good solvent and poor solvent, respectively. In the experiment, the good solvent containing compound $2\left(0.35 \mathrm{~mL}, 4 \mathrm{mmol} \cdot \mathrm{L}^{-1}\right)$ was poured into the poor solvent containing CTAB $\left(100 \mathrm{~mL}, 3 \mathrm{mmol} \cdot \mathrm{L}^{-1}\right)$. The mixture was placed for $48 \mathrm{~h}$ and centrigugated. The expected solid was washed with water and dried with vacuum.

\section{Results and Discussion}

\section{1. SEM Images of Compound 2}

The SEM images were obtained by QuantaTM450 FEI coating it with Au (Fig. 1). From Fig. 1, compound 2 could assemble into flakiness on the whole. The width of flakiness was about $500 \mathrm{~nm}$ according to the scale. However, the size of flakiness was not very well-distributated which may be related with the concentration of compound 2 and the selection of poor solvent. The preparation of nano-material of compound $\mathbf{2}$ with other concentration and solvent was undergoing.

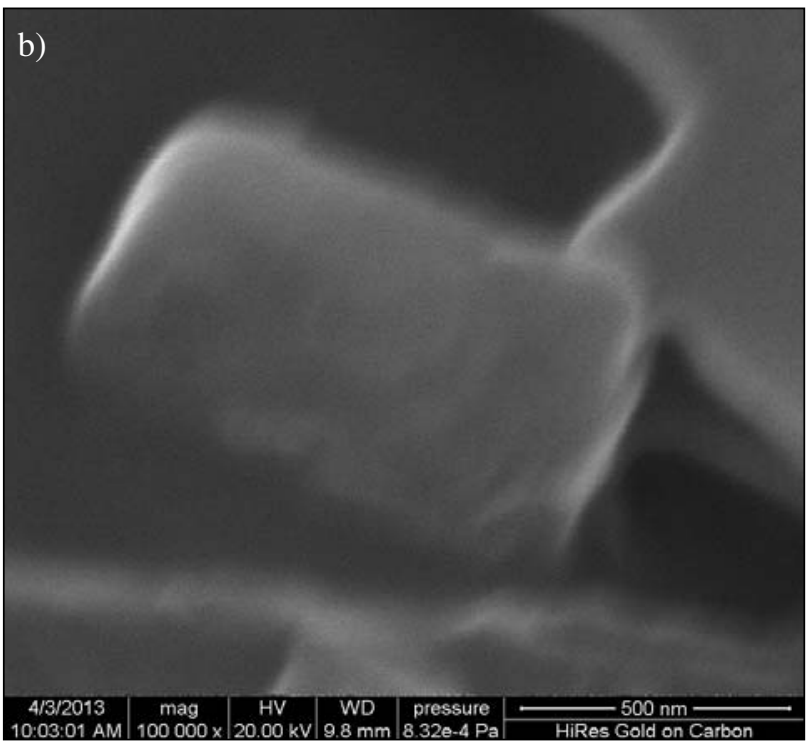




\section{2. UV-vis Spectral Titration}

The binding properties of four compounds with various anions were investigated through UV-vis titration experiment. The detail method was that the standard tetrabutylammonium salt solution of anion was added to dry DMSO solution of compounds at $298 \mathrm{~K}$. In the absence of anion, compound $1\left(4.0 \times 10^{-5} \mathrm{~mol} \cdot \mathrm{L}^{-1}\right.$ in DMSO $)$ displayed one obvious absorption peak at $350 \mathrm{~nm}$ (Fig. 2). Significant spectral changes were observed upon the addition of $\mathrm{AcO}^{-}$to the solution of compound 1. Upon the addition of $\mathrm{AcO}^{-}$, the absorption intensity of compound $\mathbf{1}$ at about $350 \mathrm{~nm}$ decreased and a new peak centered at 475 $\mathrm{nm}$ appeared gradually. In general, the red-shift phenomenon of absorption peak was occurred with the stepwise addition of $\mathrm{AcO}^{-}$. At the same time, one clear isosbestic point appeared at $387 \mathrm{~nm}$ which indicated compound $\mathbf{1}$ interacted with $\mathrm{AcO}^{-}$by hydrogen bond and the stable complex was formed between host and guest. ${ }^{33}$ Noticebly, the colorless solution of compound $\mathbf{1}$ turned into orange after the $\mathrm{AcO}^{-}$anion was added (Fig. 3). The color change was attributed to the significant formation of new absorption peak at $450 \mathrm{~nm}$. Interestingly, the orange solution, host-
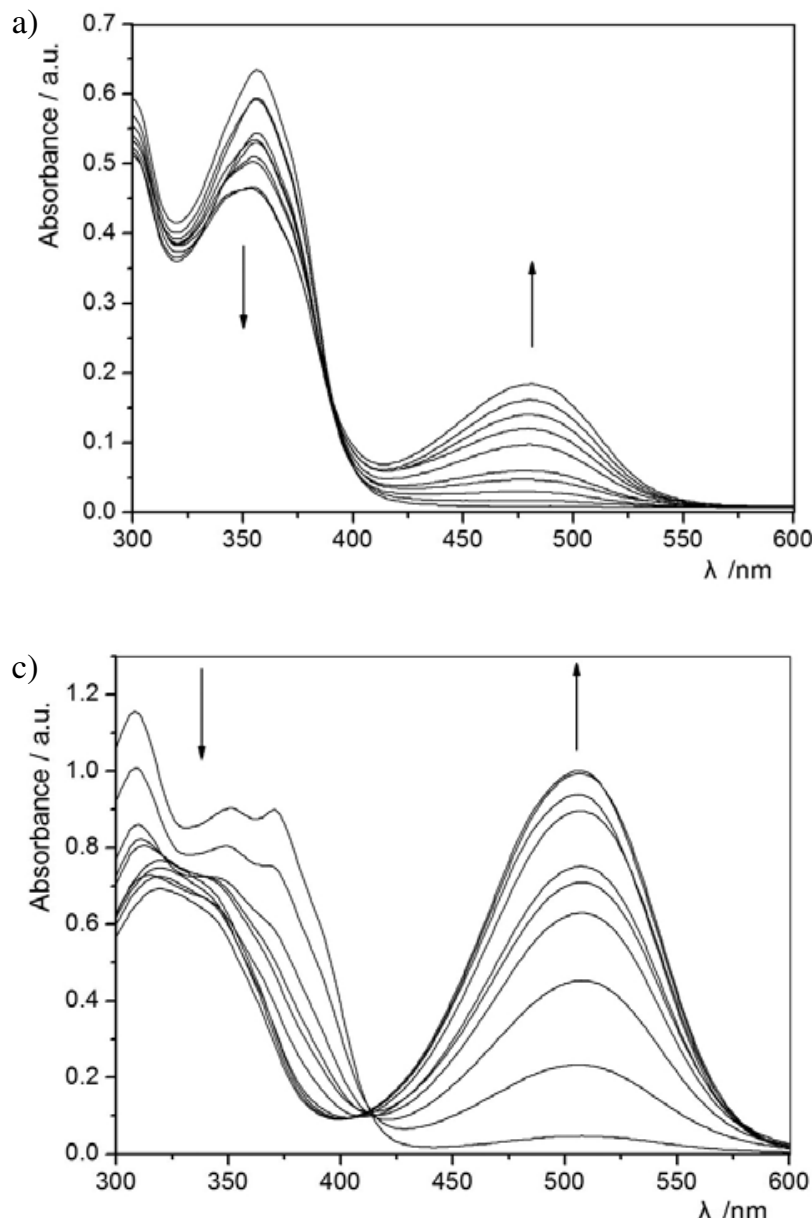

guest complexation $\left(\mathbf{1}-\mathrm{AcO}^{-}\right)$, changed back to colorless after a small quantity of protic solvent (such as $\mathrm{H}_{2} \mathrm{O}$ or $\mathrm{MeOH})$ was added to it. The above observations suggested the solvent, hydrogen-bond donor, destroyed the binding between compound $\mathbf{1}$ and $\mathrm{AcO}^{-}$and also demonstrated the binding between host and guest was hydrogenbond interaction in essence. ${ }^{34,35}$ The addition of $\mathrm{F}^{-}$also induced the spectral change of compound $\mathbf{1}$, however the spectral change was not as sensitive as the addition of acetate ion (Fig. 4). The above results maybe suggested the binding ability of $\mathrm{F}^{-}$was weaker than that of $\mathrm{AcO}^{-}$with compound $\mathbf{1}$. The following affinity constants of compounds with various anions could prove this guess. The additions of $\mathrm{H}_{2} \mathrm{PO}_{4}^{-}, \mathrm{Cl}^{-}, \mathrm{Br}^{-}$and $\mathrm{I}^{-}$virtually led to very weak spectral response of compound $\mathbf{1}$ which indicated the interactions of host-guest were very weak and could be ignored (Fig. 4).

The acidity of this kind of compounds can be tuned by changing the electron property of the substituent on the ortho- or para- position. Therefore the anion binding ability also can be tuned according to resonance structure. ${ }^{36}$ Compound 2 (o-Br), $3(o, p-\mathrm{Br})$ and $\mathbf{4}\left(p-\mathrm{NO}_{2}\right)$ containing
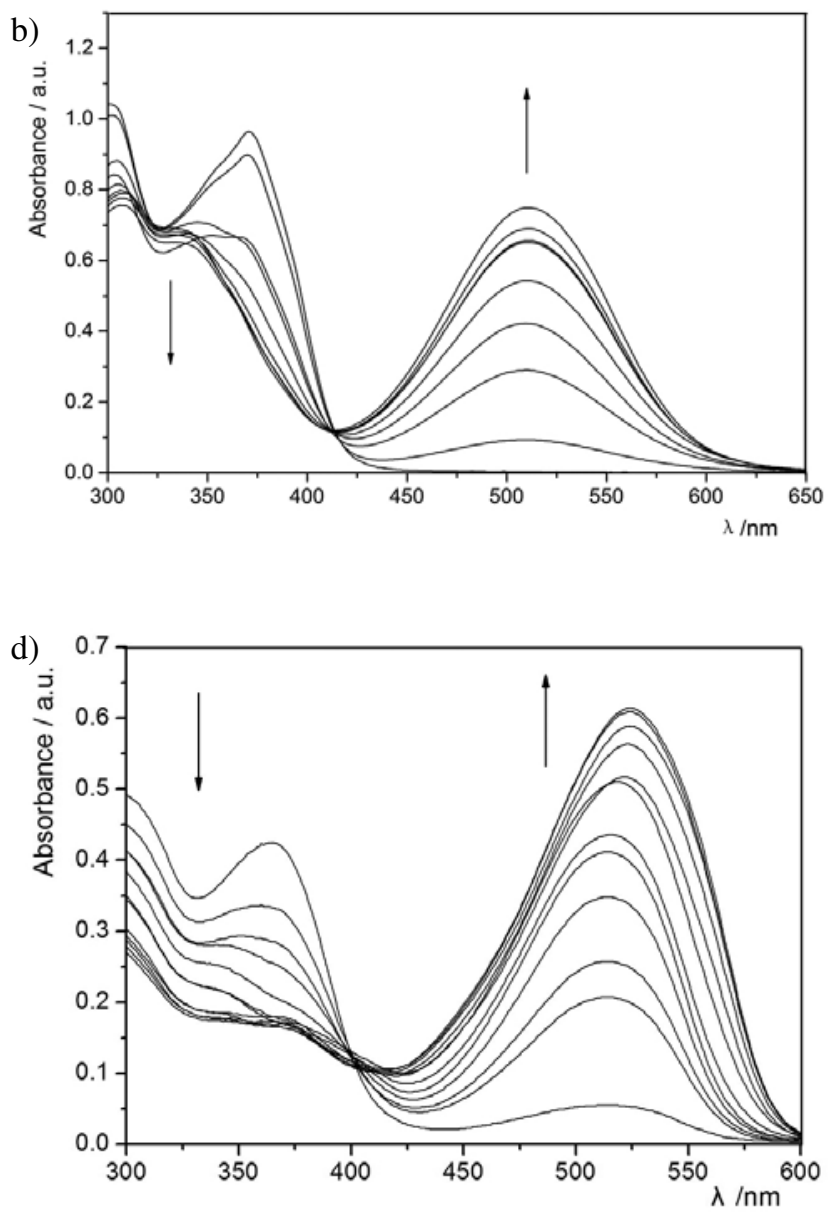

Fig. 2. UV-vis spectral changes of four compounds $\left(4.0 \times 10^{-5} \mathrm{~mol} \cdot \mathrm{L}^{-1}\right)$ upon the addition of $\mathrm{AcO}^{-}\left(0-160 \times 10^{-5} \mathrm{~mol} \cdot \mathrm{L}^{-1}\right)$, a) $\mathbf{1}$, b) $\mathbf{2}$, c) $\mathbf{3}$, d) 4 ; Arrows indicate the direction of increasing anion concentration. 
a)

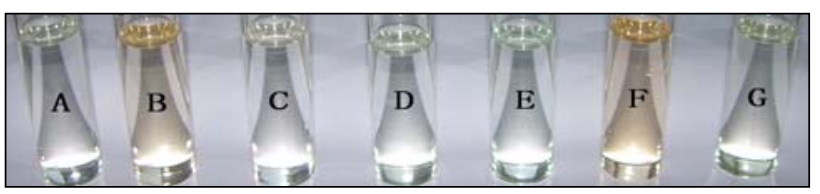

b)

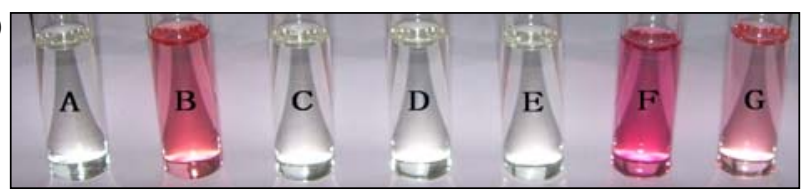

c)

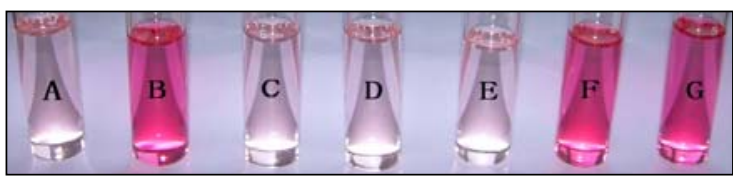

d)

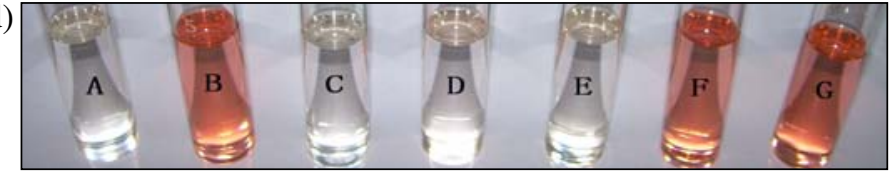

Fig. 3. Color changes of four compounds $\left(4.0 \times 10^{-5} \mathrm{~mol} \cdot \mathrm{L}^{-1}\right)$ in DMSO in absence and presence of different anions. a) 1; b) 2; c) 3; d) 4. (A: only compound; $\mathrm{B}$ : compound +10 equiv. $\mathrm{F}^{-} ; \mathrm{C}$ : compound +10 equiv. $\mathrm{Cl}^{-}$; $\mathrm{D}$ : compound +10 equiv. $\mathrm{Br}^{-} ; \mathrm{E}$ : compound +10 equiv. $\mathrm{I}^{-} ; \mathrm{F}$ : compound + 10 equiv. $\mathrm{AcO}^{-}$; $\mathrm{G}$ : compound +10 equiv. $\mathrm{H}_{2} \mathrm{PO}_{4}^{-}$).

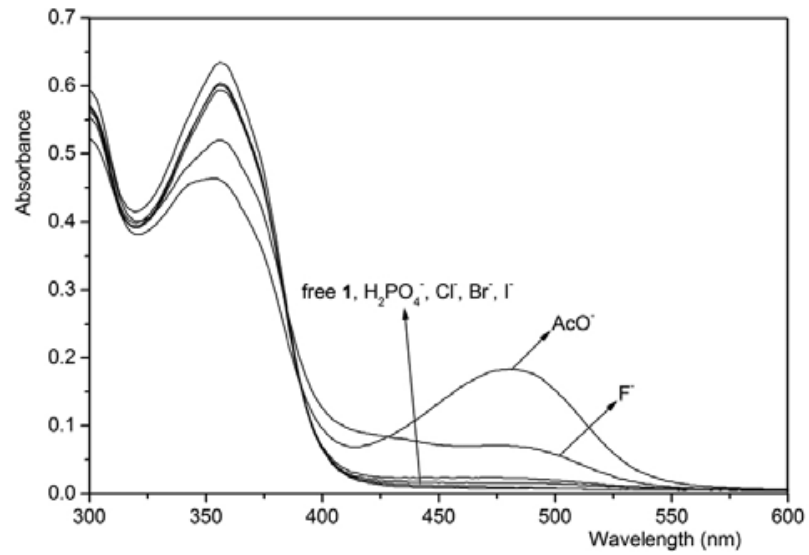

Fig. 4. Changes in absorption spectra of compound $1\left(4.0 \times 10^{-5}\right.$ $\left.\mathrm{mol} \cdot \mathrm{L}^{-1}\right)$ in presence of anions $\left(8.0 \times 10^{-4} \mathrm{~mol} \cdot \mathrm{L}^{-1}\right)$ tested.

electron-withdrawing substituent were synthesized in order to investigate the effect of electron properties of substituent on the hydrogen-bond. As expected, UV-vis spectra of 2,3 and 4 indeed exhibited changes (Fig. 2b, 2c and $2 \mathrm{~d})$. The color of solution also changed and so these compounds could be used to detect anions by "naked-eye" (Fig. 3). The additions of other anions including $\mathrm{F}^{-}$, $\mathrm{H}_{2} \mathrm{PO}_{4}^{-}$induced similar spectral changes, however, the additions of $\mathrm{Cl}^{-}, \mathrm{Br}^{-}$, and $\mathrm{I}^{-}$did not induce any spectral response for $\mathbf{2}, 3$ and 4 .

\section{3. Fluorescence Response}

The photophysical responses of four compounds toward additions of various anions tested were also investigated. Just as Fig. 5 showed, compound 1 exhibited an emission peak centered at $375 \mathrm{~nm}$ with a shoulder at 325 $\mathrm{nm}$. Upon the addition of $\mathrm{AcO}^{-}$into the solution of compound $\mathbf{1}$, the fluorescence emission was strengthened which showed $\mathrm{AcO}^{-}$interacted with hydrogen atoms of phenol groups and hydrogen bonds formed between compound $\mathbf{1}$ and anion. Two possible mechanisms may interpret the fluorescent enhancement: (1) inhibition of photoinduced electronic transfer (PET) and (2) the guest bin- ding-induced rigidity of the host molecule. ${ }^{37-39}$ Without the addition of $\mathrm{AcO}^{-}$, the hydrogen atoms of free compound 1 could form an intramolecular hydrogen bond with the nitrogen atom of Shiff base. The above structure may lead to a photoinduced electron transfer and the fluorescence was weak. However, the electron transfer from compound 1 to the fluorophore became more feasible when the acetate anion was added to the host solution. Then the binding sites resulted in the PET inhibition and the emission intensity was enhanced. Similar spectral changes were observed upon the addition of $\mathrm{F}^{-}$or $\mathrm{H}_{2} \mathrm{PO}_{4}^{-}$. On the other hand, no significant spectral changes were observed upon the titration of 1 with $\mathrm{Cl}^{-}, \mathrm{Br}^{-}, \mathrm{I}^{-}$, signifying compound 1 showed insignificant binding affinity toward these anions which could be ignored.

The intensity of emission spectra all increased after acetate anion was added to compound $\mathbf{2}, \mathbf{3}$ and $\mathbf{4}$, respectively (Fig. 5). For compound $\mathbf{2}$, the emission spectra centered at $425 \mathrm{~nm}$ was shifted to the long wave direction (437 $\mathrm{nm}, \Delta \lambda=12 \mathrm{~nm}$ ). Two emission peaks (337 nm and 412 $\mathrm{nm}$ ) incorporated one peak $(380 \mathrm{~nm})$ for compound 3. However, two broad emission peaks changed to sharp (410 $\mathrm{nm}$ and $438 \mathrm{~nm}$ ) for compound 4 . The above observation may be related with the different structures of four compounds.

\section{4. Affinity Constant}

Compound 1 interacted with anions as the binding ratio of 1:1 according to Job-plot curve. The affinity constants were obtained using the method of non-linear least squares calculation and listed in Table $1 .^{40-42}$ The binding ability trend of four compounds to anions followed the order of: $\mathrm{AcO}^{-}>\mathrm{F}^{-}>\mathrm{H}_{2} \mathrm{PO}_{4}^{-}>>\mathrm{Cl}^{-} \sim \mathrm{Br}^{-} \sim \mathrm{I}^{-}$. It was apparent that the binding ability for specific anions can be rationalized on the basis of the anion's basicity and the host-guest interaction. However, multiple hydrogen-bond interactions were also necessary in high-affinity anion binding sites. As expected from their basicity, $\mathrm{AcO}^{-}, \mathrm{F}^{-}$ and $\mathrm{H}_{2} \mathrm{PO}_{4}^{-}$will bind more strongly than the other anions studied; in addition, the triangle configuration of $\mathrm{AcO}^{-}$ion may well match four compounds in terms of shape and 

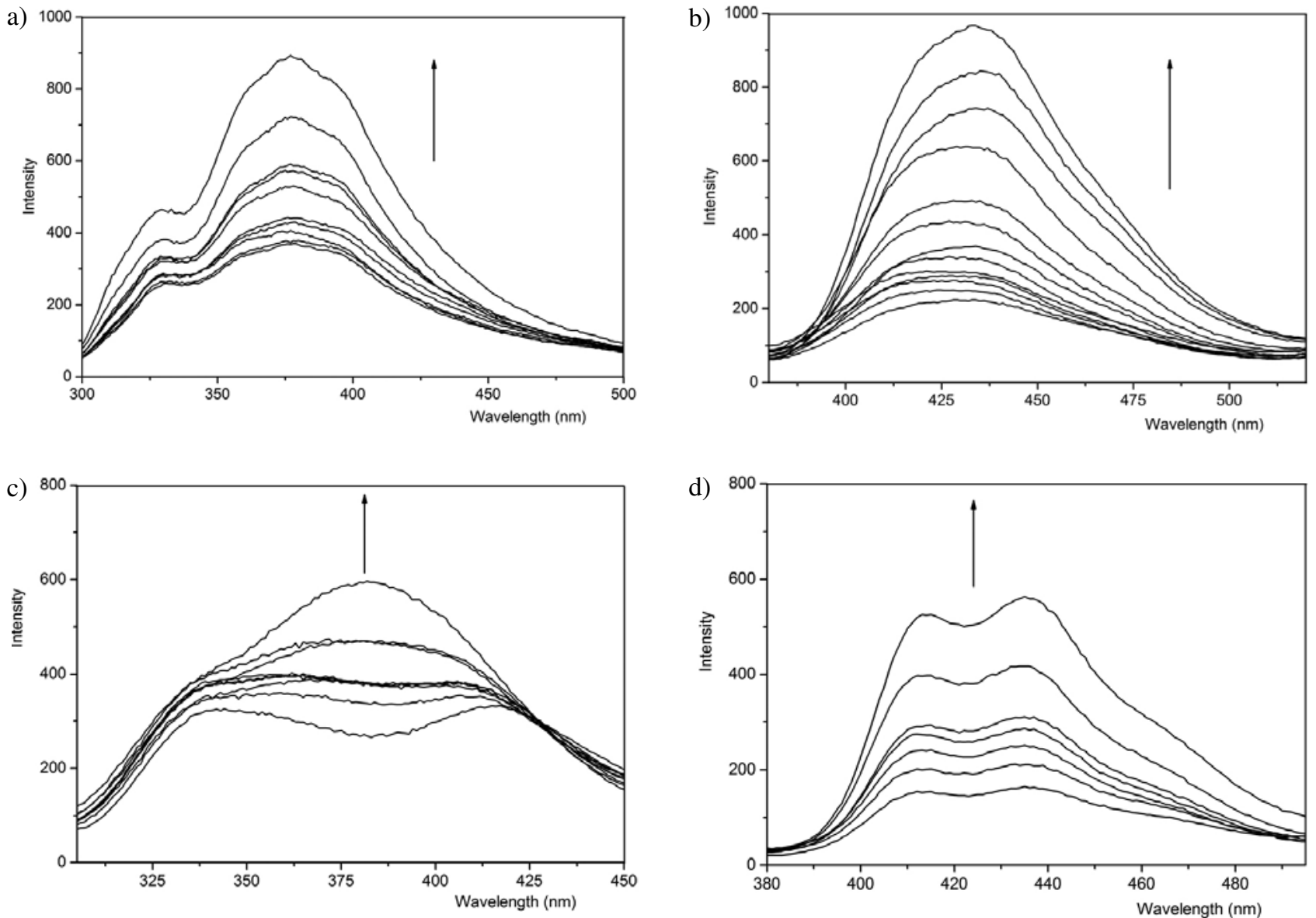

Fig. 5. Changes in the emission spectra of compounds $\left(4.0 \times 10^{-5} \mathrm{~mol} \cdot \mathrm{L}^{-1}\right)$ in absence and presence of $\mathrm{AcO}^{-}\left(0 \sim 80 \times 10^{-5} \mathrm{~mol} \cdot \mathrm{L}^{-1}\right)$, a) compound 1 , $\lambda_{\mathrm{ex}}=284 \mathrm{~nm} ; \mathrm{b}$ ) compound $2, \lambda_{\mathrm{ex}}=355 \mathrm{~nm}, \mathrm{c}$ ) compound $\left.\mathbf{1}, \lambda_{\mathrm{ex}}=284 \mathrm{~nm} ; \mathrm{d}\right)$ compound $2, \lambda_{\mathrm{ex}}=355 \mathrm{~nm}$. Arrows indicate the increasing direction of $\mathrm{AcO}^{-}$concentration.

could form multiple hydrogen bonds. Consequently, $\mathrm{AcO}^{-}$ ion can be strongly bound based on affinity constant. For the same anion, the binding ability followed the order of: $\mathbf{4}>\mathbf{3}>\mathbf{2}>\mathbf{1}$. This order was consistent with the ability of electron-withdrawing, $\mathrm{NO}_{2}>o, p-\mathrm{Br}>o-\mathrm{Br}>\mathrm{H}$. The stronger electron-withdrawing ability was, the easier the electron transferred from $\mathrm{OH}$ to electron-withdrawing group. So, the anion binding ability of compound $\mathbf{4}$ was strongest among four compounds, and compound 1 without electron-withdrawing was weakest. In addition, the intramolecular hydrogen bond could improve the acidity of receptor and so the anion binding ability could be strengthened (proved by theoretical investigation). Moreover, the affinity constants obtained by UV-vis data were in the same order of magnitude with fluorescence data. The above results indicated the affinity constants obtained by UV-vis and fluorescence data were proved each other.

\section{5. Interference Experiment}

According to the affinity constants, the binding ability of four compounds with $\mathrm{AcO}^{-}$ion was the strongest

Table 1. Affinity constants of compounds with various anions

\begin{tabular}{lccccc}
\hline Anion $^{\mathbf{a}}$ & & $\mathbf{K}_{\mathbf{s}}(\mathbf{1})$ & $\mathbf{K}_{\mathbf{s}}(\mathbf{2})$ & $\mathbf{K}_{\mathbf{s}}(\mathbf{3})$ & $\mathbf{K}_{\mathbf{s}}(\mathbf{4})$ \\
\hline $\mathrm{F}^{-}$ & Absorption & $(2.56 \pm 0.02) \times 10^{3}$ & $(1.23 \pm 0.27) \times 10^{4}$ & $(3.89 \pm 0.08) \times 10^{4}$ & $(6.69 \pm 0.07) \times 10^{4}$ \\
& Emission & $(3.31 \pm 0.45) \times 10^{3}$ & $(1.54 \pm 0.21) \times 10^{4}$ & $(3.66 \pm 0.14) \times 10^{4}$ & $(5.97 \pm 0.11) \times 10^{4}$ \\
$\mathrm{AcO}^{-}$ & Absorption & $(7.21 \pm 0.13) \times 10^{3}$ & $(2.19 \pm 0.23) \times 10^{4}$ & $(5.20 \pm 0.07) \times 10^{4}$ & $(8.17 \pm 0.12) \times 10^{4}$ \\
& Emission & $(7.58 \pm 0.21) \times 10^{3}$ & $(2.47 \pm 0.33) \times 10^{4}$ & $(5.42 \pm 0.22) \times 10^{4}$ & $(8.65 \pm 0.28) \times 10^{4}$ \\
$\mathrm{H}_{2} \mathrm{PO}_{4}{ }^{-}$ & Absorption & $\mathrm{ND}^{\mathrm{b}}$ & $(9.71 \pm 0.14) \times 10^{2}$ & $(2.88 \pm 0.06) \times 10^{4}$ & $(6.73 \pm 0.04) \times 10^{4}$ \\
& Emission & $\mathrm{ND}$ & $(8.22 \pm 0.56) \times 10^{2}$ & $(2.95 \pm 0.39) \times 10^{4}$ & $(5.86 \pm 0.72) \times 10^{4}$ \\
\hline
\end{tabular}

${ }^{a}$ All anions were added in the form of tetra-n-butylammonium (TBA) salts. ${ }^{\mathrm{b}}$ The affinity constant could not be determined. 
among the anions tested. The above results derived from the condition that only $\mathrm{AcO}^{-}$ion existed. We determined the interference experiment whether the binding ability of $\mathrm{AcO}^{-}$was influenced by the addition of other anions tested (Fig. 6). According to UV-vis experimental data, the spectral responses of compound 2 were different when various anions $\left(\mathrm{F}^{-}, \mathrm{AcO}^{-}\right.$and $\left.\mathrm{H}_{2} \mathrm{PO}_{4}^{-}, 8.0 \times 10^{-5} \mathrm{~mol} \cdot \mathrm{L}^{-1}\right)$ were added separately. As shown in Fig. 6, the spectral response of $\mathbf{2}$ upon the addition of mixed anions was almost as the same as the addition of only $\mathrm{AcO}^{-}$which suggested the binding ability of $\mathrm{AcO}^{-}$with compound 2 was not interfered by the existence of other anions. Similarly, the same result also existed in the interaction of other compounds with $\mathrm{AcO}^{-}$.

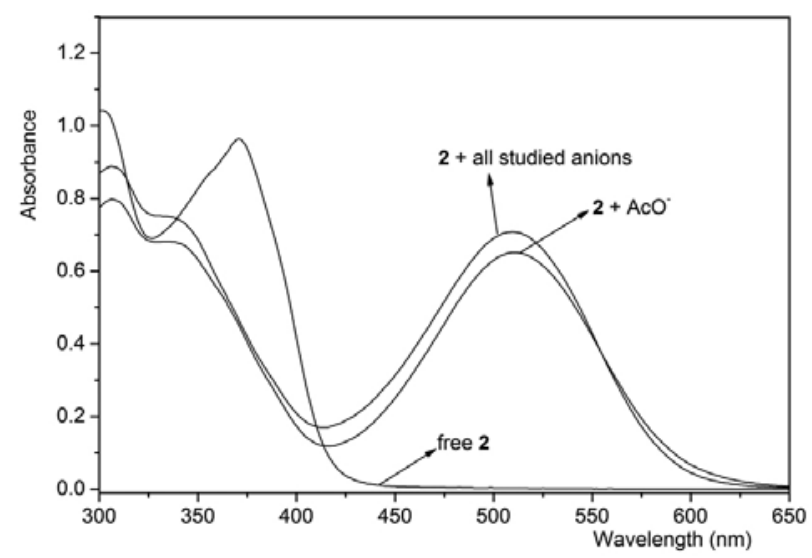

Fig. 6. UV-vis spectral changes of compound $2\left(4.0 \times 10^{-5} \mathrm{~mol} \cdot \mathrm{L}^{-1}\right)$ upon the addition of anions $\left(8.0 \times 10^{-5} \mathrm{~mol} \cdot \mathrm{L}^{-1}\right)$.

\section{6. ${ }^{1} \mathrm{H}$ NMR Titration}

In order to look into the anion binding property of four compounds, ${ }^{1} \mathrm{H}$ NMR titration of compound 2 with $\mathrm{AcO}^{-}$was determined as an example. Free compound $\mathbf{2}$ displayed two peaks at 11.21 and $11.11 \mathrm{ppm}$ in the downfield region which were attributed to $-\mathrm{OH}$ groups (Fig. 7). Upon the addition of $\mathrm{AcO}^{-}$stepwise, the signal of $-\mathrm{OH}$ weakened, shifted to the downfield gradually and disappeared thoroughly when the concentration of $\mathrm{AcO}^{-}$was 1 equiv. of compound 2 . While slight upfield of $\mathrm{CH}$ protons $(7.55-7.49,6.97-6.92 \mathrm{ppm})$ in the aromatic was also observed. The above observation indicated the interacted sites of host-gust complex were $-\mathrm{OH}$ groups and the hydrogen bonds formed. After $\mathrm{H}$-bonding formed, shield effect existed in the region of $-\mathrm{OH}$ and $\mathrm{AcO}^{-}$. Then, the proton peak of $-\mathrm{OH}$ shifted to the downfield direction. While, for non-interacted sites, aromatic cycle, deshield effect enhanced and their protons shifted to the upfield direction. The formation of hydrogen bonds changed ICT property of compound $\mathbf{1}$ and ultimately resulted in the observed color and spectral changes.

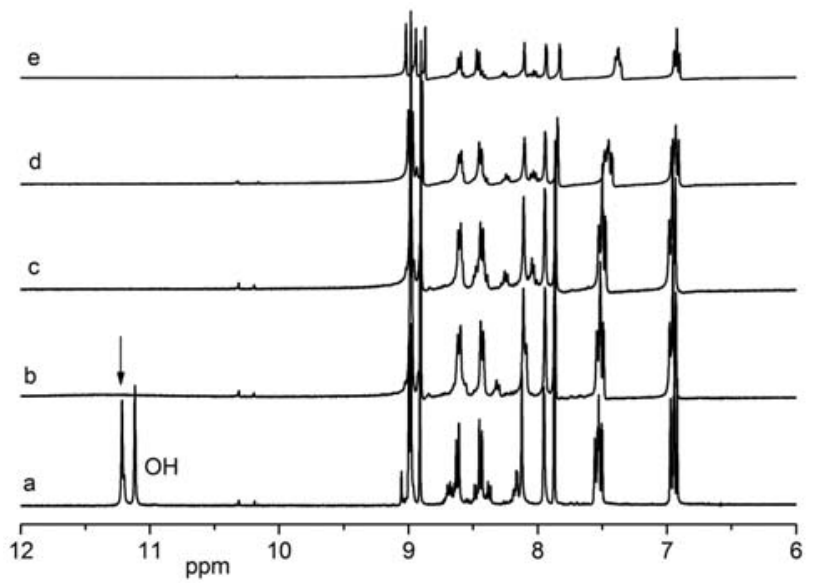

Fig. 7. Portion of ${ }^{1} \mathrm{H}$ NMR spectra of compound $2\left(0.02 \mathrm{~mol} \cdot \mathrm{L}^{-1}\right)$ in DMSO- $d_{6}$ in the presence of increasing amount of $\mathrm{AcO}^{-}$: a) free $\mathbf{1}$; b) $\mathbf{1}+0.5$ equiv.; c) $\mathbf{1}+1.0$ equiv.; d) $\mathbf{1}+2.0$ equiv.; e) $\mathbf{1}+5.0$ equiv. of $\left[(\mathrm{n}-\mathrm{Bu})_{4} \mathrm{~N}\right] \mathrm{AcO}$.

\section{7. Theoretical Investigation}

The geometries of four compounds were optimized (Fig. 8) using HF (Hartree-Fock) method with basis sets 3-21G. The calculation was performed with Gaussian03 program. ${ }^{43}$ From Fig. 8, the distances of hydrogen atom in one interacted site $(-\mathrm{OH})$ with near nitrogen atom were $1.046 \AA, 1.594 \AA, 1.593 \AA, 1.551 \AA$ in compound $\mathbf{1}, \mathbf{2}, \mathbf{3}$ and 4 , respectively. The corresponding minimum energies were $-1549.3,-11793.8,-11794.1$ and $-8761.4 \mathrm{hf}$. Clearly, minimum energy of compound was related with hydrogen bonds length. The shorter the hydrogen bond length was, the higher the minimum energy was. This phenomenon showed intramolecular hydrogen bond existed in four compounds and stable six-member cycle formed. In addition, the hydrogen atom in other interacted site $(-\mathrm{OH})$ also could form intramolecular hydrogen bonds with near bromide or oxygen atom in compound $2,3,4$.
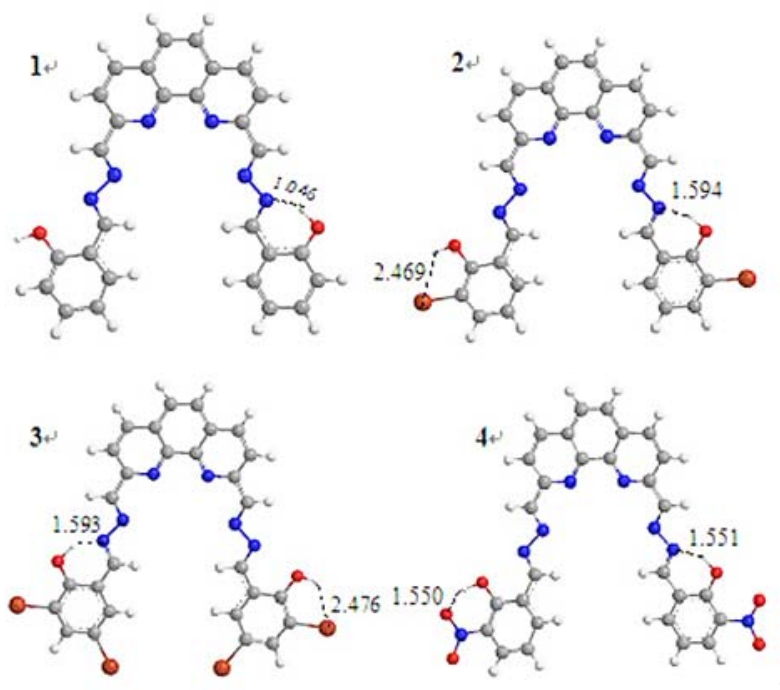

Fig. 8. Optimized structures of four compounds 


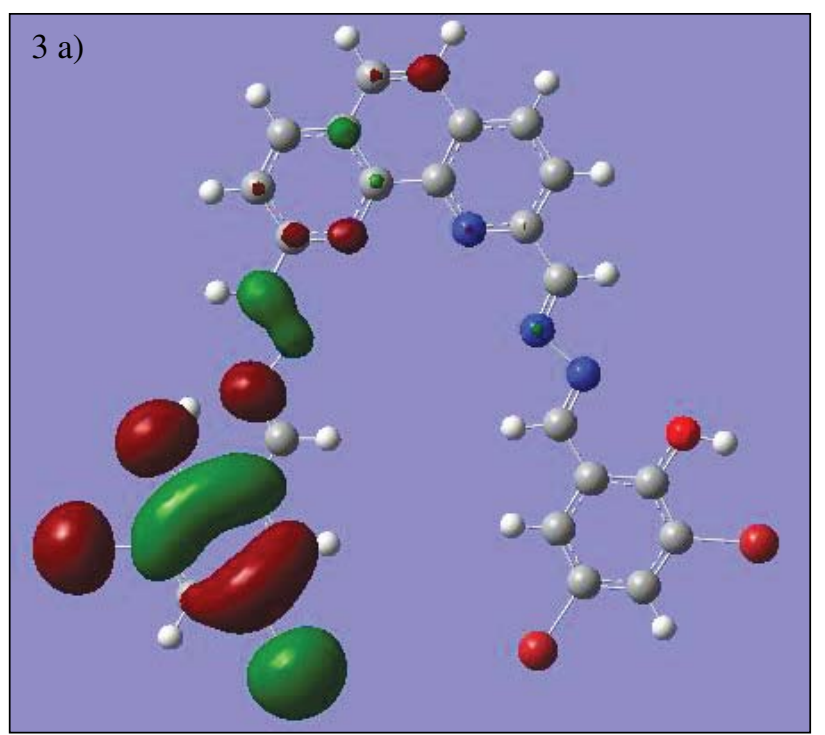

Fig. 9. Molecular orbital level of compound 3, a) HOMO; b) LUMO.

These results showed four compounds could bind anion through multiple hydrogen bonds. Therefore, the binding ability of oxyanion, $\mathrm{AcO}^{-}$, with compounds was the strongest among anions tested.

In addition, selected frontier orbitals for compound $\mathbf{3}$ were shown in Fig. 9. Molecular frontier orbital was introduced in order to explain red-shift phenomenon existing in absorption spectra induced by electron transition of frontier orbital. The highest occupied orbital (HOMO) density in compound $\mathbf{3}$ was mainly localized on one phenyl cycle moiety, while the lowest unoccupied orbital (LUMO) density was localized on the whole molecular, which suggested the red-shift phenomenon in UV-vis spectra of hostguest was caused by the electron transition of HOMO.

\section{Conclusion}

In conclusion, four colorimetric anion sensors involving phenanthroline and phenol groups were successfully synthesized and optimized. They interacted with anions by hydrogen bond and showed the strong binding ability for $\mathrm{AcO}^{-}$without the interference of other anions studied. The anion binding ability was related to the electron properties of ortho- or para-substituents on benzene. The correlation between the electron properties of substituents and the binding ability will be a very useful clue to design stronger receptors to bind a certain anion. What's more, the organic nano-material of compound $\mathbf{2}$ was also prepared. The flakiness appearance of nano-material was not good which might be related to the concentration of compound 2 and the selection of poor solvent. The appearance of compound 2 will turn to better by changing the concentration of compound $\mathbf{2}$ and poor solvent. The combination of anion receptor and nano-material will be an efficient

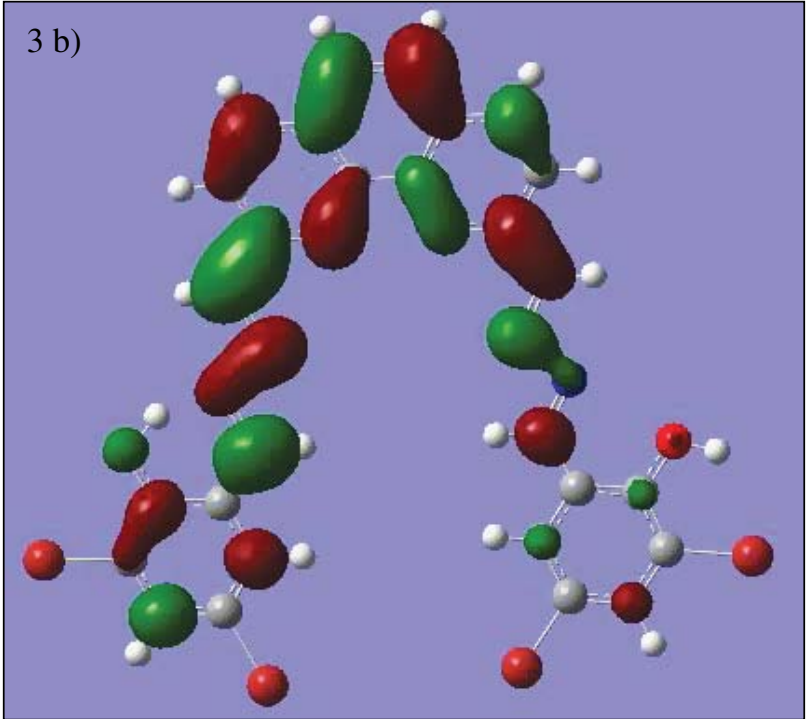

way to construct new responsive materials. The innovative aspect of this manuscript is that phenanthroline nano-material is applied to anion recognition and experiment results are accordance with theoretical investigation. This study has convincingly shown the potential of phenanthroline derivatives for future applications in the design of anion responsive materials in supramolecular chemistry.

\section{Acknowledgment}

This work was supported by the National Natural Science Foundation of China (81301269, 21071047), Program for New Century Excellent Talents in University (NCET-11-0944), Excellent Youth Foundation of Henan Scientific Committee (124100510004), Program for Science \& Technology Innovation Talents in Universities of Henan Province (2011HASTIT010).

\section{References}

1. C. Caltagirone, P. A. Gale, Chem. Soc. Rev., Chem. Soc. Rev. 2012, 41, 480-520.

2. S. Kado, H. Otani, Y. Nakahara, K. Kimura, Chem. Commun. 2013, 49, 886-888. http://dx.doi.org/10.1039/C2CC38052H

3. L. E. Santos-Figueroa, M. E. Moragues, E. Climent, A. Agostini, R. Martínez-Máñez, F. Sancenón, Chem. Soc. Rev. 2013, 42, 3489-3613. http://dx.doi.org/10.1039/c3cs35429f

4. G. T. Spence, C. Chan, F. Szemes, P. D. Beer, Dalton Trans., 2012, 13474-13485 http://dx.doi.org/10.1039/c2dt31640d

5. H. Sharma, H. J. Guadalupe, J. Narayanan, H. Hofeld, T. 
Pandiyan, N. Singh, Anal. Methods 2013, 5, 3880-3887. http://dx.doi.org/10.1039/c3ay40434j

6. H. Durmaz, A. Sanyal, G. Hizal, U. Tunca, Polym. Chem. 2012, 3, 825-835. http://dx.doi.org/10.1039/C1PY00471A

7. Z. Xu, S. K. Kim, J. Yoon, Chem. Soc. Rev. 2010, 39, $1457-$ 1466. http://dx.doi.org/10.1039/b918937h

8. X. F. Shang, X. J. Li, N. K. Xi, Y. T. Zhai, J. L. Zhang, X. F. Xu, Sensor. Actuat. B: Chem. 2011, 160, 1112-1119. http://dx.doi.org/10.1016/j.snb.2011.09.035

9. A. Ojida, Y. Mito-oka, K. Sada, I. Hamachi, J. Am. Chem. Soc. 2004, 26, 2454-2463. http://dx.doi.org/10.1021/ja038277x

10. Z. Yang, K. Zhang, F. Gong, S. Li, J. Chen, J. S. Ma, L. N. Sobenina, A. I. Mikhaleva, B. A. Trofimov, G. Yang, J. Photochem. Photobiolo. A: Chem. 2011, 217, 29-34. http://dx.doi.org/10.1016/j.jphotochem.2010.09.012

11. T. Y. Joo, N. Singh, G. W. Lee, D. O. Jiang, Tetrahedron Lett. 2007, 48, 8846-8850. http://dx.doi.org/10.1016/j.tetlet.2007.10.060

12. H. Tavallali, G. D. Rad, A. Parhami, E. Abbasiyan, Dyes Pigm. 2012, 94, 541-547. http://dx.doi.org/10.1016/j.dyepig.2012.03.006

13. W. W. Huang, H. Lin, H. K. Lin, Sensor. Actuat. B: Chem. 2011, 153, 404-408. http://dx.doi.org/10.1016/j.snb.2010.11.006

14. S. Goswami, R. Chakrabarty, Tetrahedron Lett. 2009, 50, 5994-5997. http://dx.doi.org/10.1016/j.tetlet.2009.08.021

15. A. Misra, M. Shahid, P. Dwivedi, Talanta 2009, 80, 532 538. http://dx.doi.org/10.1016/j.talanta.2009.07.020

16. W. W. Huang, Y. Li, H. Lin, H. K. Lin, Spectrochimica Acta Part A 2012, 86, 437-442. http://dx.doi.org/10.1016/j.saa.2011.10.064

17. F. Y. Wu, M. H. Hu, Y. M. Wu, X. F. Tan, Y. Q. Zhao, Z. J. Ji, Spectrochim. Acta Part A 2006, 65, 633-637. http://dx.doi.org/10.1016/j.saa.2005.12.022

18. Jr P. Anzenbacher, A. C. Try, H. Miyaji, V. M. Lynch, M. Marquez, J. L. Sessler, J. Am. Chem. Soc. 2000, 122, 93509351.

19. C. B. Black, B. Andrioletti, A. C. Try, C. Ruiperez, J. L. Sessler, J. Am. Chem. Soc. 1999, 121, 10438-10439. http://dx.doi.org/10.1021/ja992579a

20. J. L. Sessler, H. Maeda, T. Mizuno, V. M. Lynch, H. Furuta, Chem. Commun. 2002, 862-863. http://dx.doi.org/10.1039/b111708d

21. J. L. Sessler, G. D. Pantos, E. Katayev, V. M. Lynch, Org. Lett. 2003, 5, 4141-4144. http://dx.doi.org/10.1021/o10355635

22. M. Jesús Seguí, J. Lizondo-Sabater, A. Benito, Talanta 2007, 71, 333-338. http://dx.doi.org/10.1016/j.talanta.2006.04.005

23. A. P. Davis, J. J. Perry, R. S. Warham, Tetrahedron Lett. 1998, 39, 4569-4572.
http://dx.doi.org/10.1016/S0040-4039(98)00808-9

24. K. J. Winstanley, D. K. Smith, J. Org. Chem. 2007, 72, 2803-2815. http://dx.doi.org/10.1021/jo0623989

25. S. I. Kondo, T. Harada, R. Tanaka, M. Unno, Org. Lett. 2006, 8, 4621-4624.

http://dx.doi.org/10.1021/ol061822p

26. V. Amendola, D. Esteban-Gomez, L. Fabbrizzi, M. Licchelli, Acc. Chem. Res. 2006, 39, 343-353. http://dx.doi.org/10.1021/ar0501951

27. K. J. Winstanley, A. M. Sayer, D. K. Smith, Org. Biomol. Chem. 2006, 4, 1760-1767.

http://dx.doi.org/10.1039/b516433h

28. E. R. Libra, M. J. Scott, Chem. Commun. 2006, 1485-1487. http://dx.doi.org/10.1039/b517944k

29. X. P. Bao, J. H. Yu, Y. H. Zhou, Sensor. Actuat. B: Chem. 2009, 140, 467-472. http://dx.doi.org/10.1016/j.snb.2009.04.056

30. L. M. Zimmermann-Dimer, V. G. Machado, Dyes Pigm. 2009, 82, 187-195. http://dx.doi.org/10.1016/j.dyepig.2008.12.013

31. H. Liu, J. Xu, Y. Li, Acc. Chem. Res. 2010, 43, 1496-1508. http://dx.doi.org/10.1021/ar100084y

32. F. S. Kim, G. Q. Ren, S. A. Jenekhe, Chem. Mater. 2011, 23, 682-732. http://dx.doi.org/10.1021/cm102772x

33. M. Boiocchi, L. D. Boca, D. E. Gomez, L. Fabbrizzi, M. Licchelli, E. Monzani, J. Am. Chem. Soc. 2004, 126, 1650716514. http://dx.doi.org/10.1021/ja045936c

34. S. I. Kondo, A. Fukuda, T. Yamamura, R. Tanaka, M. Unno, Tetrahedron Lett. 2007, 48, 7946-7949. http://dx.doi.org/10.1016/j.tetlet.2007.09.067

35. L. Guo, Q. L. Wang, Q. Q. Jiang, Q. J. Jiang, Y. B. Jiang, J. Org. Chem. 2007, 72, 9947-9953. http://dx.doi.org/10.1021/jo701823d

36. J. Ju, M. Park, J. M. Suk, M. S. Lah, K. S. Jeong, Chem. Commun. 2008, 3546-3548. http://dx.doi.org/10.1039/b804284e

37. Z. H. Lin, Y. G. Zhao, C. Y. Duan, B. G. Zhang, Z. P. Bai, Dalton Trans. 2006, 3678-3684.

http://dx.doi.org/10.1039/b601282e

38. D. H. Lee, J. H. Im, J. H. Lee, J. I. Hong, Tetrahedron Lett. 2002, 43, 9637-9640. http://dx.doi.org/10.1016/S0040-4039(02)02443-7

39. S. Watanabe, O. Onogawa, Y. Komatau, K. Yoshida, J. Am. Chem. Soc. 1998, 120, 229-230. http://dx.doi.org/10.1021/ja973263a

40. Y. Liu, B. H. Han, H. Y. Zhang, Curr. Org. Chem. 2004, 8, 35-46. http://dx.doi.org/10.2174/1385272043486061

41. Y. Liu, C. C. You, H. Y. Zhang, Supramolecular Chemistry, Nankai University Publication Tian Jin 2001

42. J. Bourson, J. Pouget, B. Valeur, J. Phys. Chem. 1993, 97, 4552-4557.

http://dx.doi.org/10.1021/j100119a050 
43. M. J. Frisch, G. W. Trucks, H. B. Schlegel, G. E. Scuseria, et al. Gaussian 03, Revision A.1,Gaussian, Inc., Pittsburgh PA. 2003

\section{Povzetek}

Sintetizirali in optimizirali smo nove fenantrolinske derivate $(\mathbf{1}, \mathbf{2}, \mathbf{3}, \mathbf{4})$, ki vsebujejo fenolne skupine. Za spojino 2 smo pripravili še nanomaterial. Vezavne lastnosti smo preverili za številne biološke anione $\left(\mathrm{F}^{-}, \mathrm{Cl}^{-}, \mathrm{Br}^{-}, \mathrm{I}^{-}, \mathrm{AcO}^{-}\right.$in $\left.\mathrm{H}_{2} \mathrm{PO}_{4}^{-}\right)$ s teoretičnimi metodami, UV-vidno spektroskopijo, fluorescenco in ${ }^{1} \mathrm{HNMR}$ titracijskimi eksperimenti. Vse spojine imajo veliko sposobnost vezave $\mathrm{AcO}^{-}$brez interference za vezavo drugih testiranih anionov. Sposobnost za vezavo anionov lahko uravnavamo z lastnostmi orto-ali para-benzena $v$ smislu potega ali izriva elektronov. Teoretične analize so pokazale učinek znotrajmolekulske vodikove vezi med -OH in drugimi atomi v strukturi teh spojin. 